Counsellia: Jurnal Bimbingan dan Konseling 8 (1), 53-58 | Mei 2018

Copyright $@ 2017$ Universitas PGRI Madiun

ISSN: 2088-3072 (Print) / 2477-5886 (Online)

Available online at: http://e-journal.unipma.ac.id/index.php/JBK

DOI: 10.25273/counsellia.v8i1.2027

\title{
Potret Interpersonal Communication Skill Mahasiswa Calon Konselor
}

\author{
Dian Ari Widyastuti \\ Fakultas Keguruan dan Ilmu Pendidikan, Universitas Ahmad Dahlan, Yogyakarta \\ dian.widyastuti@bk.uad.ac.id
}

\begin{abstract}
Abstrak
Tujuan dari studi ini untuk mengetahui tingkat interpersonal communication skill mahasiswa calon konselor. Studi ini merupakan penelitian deskriptif kuantitatif dengan instrumen pengumpulan data berupa skala Interpersonal Communication Skill (ICS). Subjek penelitian berjumlah 105 mahasiswa baru Program Studi Bimbingan dan Konseling di salah satu perguruan tinggi di Kota Yogyakarta yang diambil melalui teknik random sampling. Analisis data menggunakan analisis statistik deskriptif, dimana pengelompokkan kriteria dihitung menggunakan rumus standar deviasi dan mean. Hasil penelitian menunjukkan bahwa sebanyak 14,29\% mahasiswa berada pada kriteria interpersonal communication skill sangat tinggi, 23,81\% mahasiswa berada pada kriteria interpersonal communication skill tinggi, 37,14\% mahasiswa berada pada kriteria interpersonal communication skill sedang, 20\% mahasiswa berada pada kriteria sinterpersonal communication skill rendah, dan 4,76\% siswa berada pada kriteria interpersonal communication skill sangat rendah. Hasil penelitian ini dapat dijadikan sebagai referensi dalam upaya mengembangkan interpersonal communication skill mahasiswa calon konselor.
\end{abstract}

Kata kunci: keterampilan komunikasi interpersonal, konselor

\begin{abstract}
The purpose of this study is to determine the interpersonal communication skill level of the counselor candidate students. This study is a quantitative descriptive study with data collection instrument in the form of Interpersonal Communication Skill (ICS) scale. The subjects of the study were 105 students of Guidance and Counseling Study Program in one of the universities in Yogyakarta City which was taken by random sampling technique. The data were analyzed using descriptive statistical analysis, where the criteria were calculated using standard deviation and mean formulas. The results showed that as many as $14.29 \%$ of students are in the criteria of interpersonal communication skill is very high, $23.81 \%$ of students are in interpersonal communication skill criteria high, $37.14 \%$ of students are on interpersonal communication skill criteria are, $20 \%$ sinterpersonal communication skills criteria are low, and $4.76 \%$ of students are in very low interpersonal communication skill criteria. The results of this study can be used as a reference in an effort to develop interpersonal communication skill prospective student counselor.
\end{abstract}

Keywords: interpersonal communication skill, counselor 


\section{PENDAHULUAN}

Penyelenggaraan layanan bimbingan dan konseling menuntut konselor untuk menggunakan sejumlah keterampilan, salah satunya keterampilan berkomunikasi, di samping berbagai keterampilan lainnya (Geldard \& Geldard, 2005). Hal tersebut senada dengan NelsonJones (2008) yang menyatakan bahwa terdapat dua hal utama dalam konseling, yaitu keterampilan komunikasi dan bertindak, serta keterampilan berpikir. Keterampilan komunikasi dan bertindak melibatkan perilaku eksternal pada konselor, sedangkan keterampilan berpikir melibatkan perilaku internal pada konselor.

Konselor hendaknya selalu mengembangkan keterampilan komunikasi agar dapat memberikan layanan dengan optimal karena pada dasarnya kinerja konselor menuntut keterlibatannya dalam interaksi sosial. Hal tersebut dibuktikan oleh hasil penelitian Nasution (dalam Anyta, 2015) yang menyatakan bahwa keterampilan komunikasi interpersonal konselor berpengaruh terhadap pembentukan konsep diri ODHA. Hasil penelitian lain menyatakan bahwa keterampilan komunikasi konselor yang baik dapat mewujudkan kenyamanan bagi orangtua siswa untuk berkonsultasi (Gumilang, 2015). Kenyamanan tersebut dapat meningkatkan hubungan interpersonal konselor dengan orangtua sehingga dapat terjalin kerjasama yang baik di antara keduanya dalam memantau dan membantu perkembangan optimal siswa.

Selaras dengan hal yang telah dipaparkan, sebagai calon konselor, mahasiswa Strata Satu (S1) Program Studi Bimbingan dan Konseling hendaknya memiliki keterampilan komunikasi interpersonal (interpersonal communication skill) yang baik. Keterampilan komunikasi interpersonal menjadi salah satu bagian dari kompetensi kepribadian yang harus dimiliki oleh konselor agar dapat memberikan layanan dengan optimal. Kompetensi kepribadian yang dimaksudkan dimana konselor dapat menampilkan kinerja berkualitas tinggi, salah satunya dengan berkomunikasi secara efektif.

\section{METODE PENELITIAN}

Studi ini merupakan jenis penelitian deskriptif kuantitatif. Subjek penelitian sebanyak 105 mahasiswa Program Studi Bimbingan dan Konseling di salah satu perguruan tinggi di Kota Yogyakarta yang diambil secara random sampling. Instrumen yang digunakan dalam studi ini adalah skala interpersonal communication skill (ICS) yang telah teruji validitas dan reliabilitasnya dengan rumus alpha cronbach berbantuan SPSS 20.0 for windows. Teknik analisis data yang digunakan yaitu analisis statistik deskriptif, dimana pengelompokkan kriteria dihitung menggunakan rumus standar deviasi dan mean. Kriteria yang dimaksudkan yaitu sangat tinggi, tinggi, sedang, rendah, dan sangat rendah.

\section{HASIL DAN PEMBAHASAN}

Berdasarkan analisis statistik deskriptif dengan rumus standar deviasi dan mean, diperoleh hasil penelitian sebagaimana pada Gambar 1. 


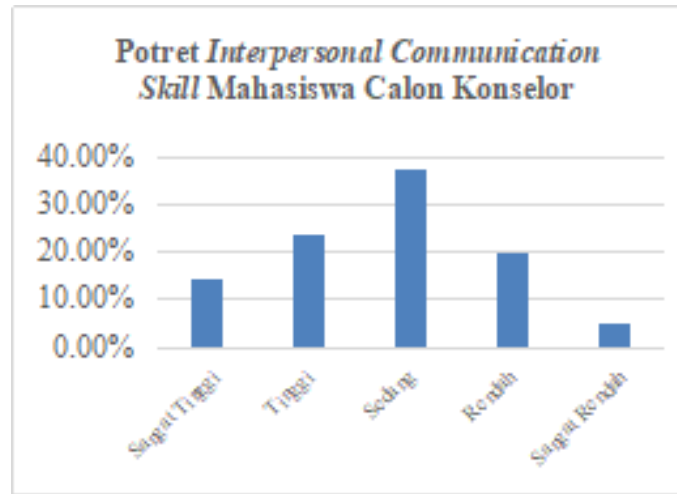

Gambar 1. Potret Interpersonal Communication Skill Mahasiswa Calon Konselor

Berdasarkan hasil penelitian, diketahui bahwa keterampilan komunikasi interpersonal (interpersonal communication skill) mahasiswa calon konselor dapat dikatakan baik, meskipun terdapat $20 \%$ mahasiswa yang masih berada dalam kategori rendah dan $4,76 \%$ berada pada kategori sangat rendah. Hal tersebut sejalan dengan hasil penelitian Gumilang (2015) yang menyatakan bahwa berdasarkan hasil penelitian evaluasi keterampilan komunikasi interpersonal pada tiga orang konselor, masih terdapat satu orang konselor yang dalam kategori kurang dibandingkan dua konselor lainnya yaitu dengan rerata skor hasil evaluasi sebesar $62 \%$. Oleh karena itu, diperlukan suatu upaya untuk mengembangkan keterampilan komunikasi interpersonal mahasiswa calon konselor sedini mungkin agar calon konselor siap untuk menjadi konselor profesional ketika terjun di lapangan.

Konselor merupakan profesi yang hadir sebagai respon terhadap kebutuhan konseli untuk memahami diri dan lingkungannya. Bimbingan dan konseling merupakan sebuah pekerjaan profesional yang dalam pelayanan ahlinya tidak hanya sekadar menerapkan seperangkat prosedur tetap, melainkan selalu berpikir dengan mengerahkan kemampuan akademik yang dikuasainya untuk melakukan layanan (Radjah, 2016).

Belakangan ini, bidang kajian dalam bimbingan dan konseling mengalami perkembangan yang sangat signifikan. Beberapa topik yang menjadi bahasan terkini di antaranya bimbingan dan konseling dalam menghadapi kekerasan, trauma, kondisi krisis, penggunaan narkotika, pada individu dengan kebutuhan khusus, krisis identitas, dan lain sebagainya. Perkembangan dalam bimbingan dan konseling tersebut menuntut konselor dalam penguasaan kompetensi karena pada dasarnya layanan bimbingan dan konseling berbasis pada teori serta merupakan proses berupa perkembangan dan intervensi (Gladding, 2012).

Bimbingan dan Konseling melibatkan hubungan antara konselor dengan konseli. Hubungan ini merupakan sebuah proses profesional yang melibatkan dua pihak yang secara bersama-sama dan bersinergi berusaha mencapai suatu tujuan bersama. Kualitas hubungan antara konselor dan konseli tampaknya paling memungkinkan untuk menciptakan pertumbuhan hubungan antar keduanya (Corey, 2015). Dengan demikian, bimbingan dan konseling melibatkan suatu hubungan profesional yang bersifat memberikan bantuan dan sangat bergantung pada kualitas kepribadian konselor. Hubungan profesional tersebut dapat tercipta melalui kesuksesan komunikasi 
interpersonal antara konselor dengan konseli.

Keterampilan komunikasi interpersonal perlu dimiliki oleh konselor dalam melaksanakan tugasnya sebagai seorang helper. Pada setiap pemberian layanan, menuntut adanya keterampilan dalam berkomunikasi, baik ketika memberikan layanan dalam bimbingan klasikal, bimbingan kelompok, konseling, layanan konsultasi, dan layanan-layanan lainnya dalam bimbingan dan konseling. Diharapkan konselor dapat mencapai tujuan layanan dengan optimal melalui keterampilan komunikasi interpersonal yang dimilikinya. Hal tersebut sesuai dengan salah satu kompetensi kepribadian yang harus dimiliki seorang konselor, di mana konselor dapat menampilkan kinerja berkualitas tinggi, salah satunya dengan berkomunikasi secara efektif.

Keterampilan komunikasi interpersonal merupakan salah satu keterampilan utama yang harus dikuasai oleh konselor untuk penyelenggaraan layanan bimbingan dan konseling. Pada prinsipnya, komunikasi merupakan hal yang paling esensial dalam kehidupan manusia, tidak hanya dalam layanan bimbingan dan konseling. Melalui komunikasi, individu dapat mengekspresikan diri dan perasaannya, membentuk jaringan sosial dan mengembangkan kepribadiannya (Zamroni, 2009). Kegagalan individu dalam berkomunikasi dapat menghambat hubungan individu dengan lingkungannya. Demikian juga apabila dikaitkan dengan layanan bimbingan dan konseling, kegagalan atau kesuksesan keterampilan komunikasi interpersonal konselor berpengaruh besar terhadap perkembangan hubungan konselor dan konseli. Lebih dari itu keterampilan komunikasi interpersonal konselor dapat berpengaruh terhadap keberhasilan suatu tujuan layanan sehingga pada akhirnya berpengaruh terhadap pencapaian perkembangan optimal konseli. Oleh karena itu, konselor secara berkelanjutan diharapkan dapat meningkatkan pemahaman dan penguasaan tentang keterampilan komunikasi interpersonal.

Peningkatan pemahaman dan penguasaan tentang keterampilan komunikasi interpersonal pada diri konselor hendaknya sedini mungkin diupayakan. Salah satu upaya yang dapat dilakukan yaitu terintegrasi dalam proses pembelajaran di perguruan tinggi, dengan menerapkan model-model pembelajaran aktif dan inovatif sehingga dapat membangun keterampilan komunikasi interpersonal mahasiswa calon konselor. Perubahan dari content transmission paradigm menuju competency based instruction menuntut penciptaan lingkungan dan pengalaman belajar bagi mahasiswa untuk mencari, menemukan, dan mengkonstruksi pengetahuan mereka sendiri. Dosen diharapkan menjadi pembimbing dan mentor, membantu mahasiswa untuk mengakses, menginterpretasikan, mengorganisasikan, dan mentransfer pengetahuan untuk memecahkan masalah yang sesungguhnya, sementara itu mahasiswa memperoleh tambahan keahlian bukan hanya dari materi yang dipelajarinya melainkan juga pengalaman pembelajaran (Pedersen \& Liu, 2003). Rosjidan (2002) menyatakan bahwa pengembangan program pendidikan BK tidak cukup memadai 
jika hanya menstandarisasi daftar matakuliah yang diperlukan sarjana BK tetapi juga harus menstandarisasikan

pengorganisasian pengalaman belajar mahasiswa yang memungkinkan tercapainya pembentukan sikap pribadi dan kompetensi profesional konselor. Melalui upaya-upaya tersebut diharapkan perguruan tinggi, khususnya Program Studi Bimbingan dan Konseling, dapat mencetak lulusan dalam bidang bimbingan dan konseling yang profesional dan dapat diandalkan dalam bidang helping profession.

\section{SIMPULAN}

Berdasarkan hasil penelitian, masih terdapat mahasiswa calon konselor yang memiliki interpersonal communication skill pada kategori rendah dan sangat rendah. Oleh karena itu, diperlukan suatu upaya untuk mengembangkan interpersonal communication skill pada mahasiswa calon konselor. Upaya tersebut dapat diintegrasikan dalam proses pembelajaran di perguruan tinggi sehingga Program Studi Bimbingan dan Konseling dapat mencetak lulusan dalam bidang bimbingan dan konseling yang profesional dan dapat diandalkan dalam bidang helping profession.

\section{DAFTAR PUSTAKA}

Anyta, Nurul Diah. (2015). Komunikasi Antarpribadi Konselor terhadap ODHA di Klinik Vct RSUD Kabupaten Karanganyar. (Online), (http://eprints.ums.ac.id/38299/4/ 02.\%20Naskah\%20Publikasi.pdf) , diakses 12 September 2017.

Corey, G. (2015). Theory and Practice of Counseling and Psychotherapy. Nelson Education.

Geldard, K., \& Geldard, D. (2005). Practical Counselling Skills: An Integrative Approach. Palgrave Macmillan.

Gladding, S. T. (2012). Counseling: A Comprehensive Profession. New Jersey: Pearson Higher Ed.

Gumilang, Surya Galang. (2015). Evaluasi Keterampilan Komunikasi Interpersonal antara Konselor dengan Siswa, Staf Sekolah, dan Orangtua. Psikopedagogia Jurnal Bimbingan dan Konseling, 4(1): 83-87).

Nelson-Jones, R. (2008). Introduction to Counselling Skills: Text and Activities. Sage.

Pedersen, S. \& Liu, M. (2003). Teachers' Beliefs about Issues in the Implementation of a StudentCentered Learning Environment. ETR\&D, 51 (2); 57-76.

Radjah, C. L. (2016). Keterampilan Konseling Berbasis Metakognisi. Jurnal Kajian Bimbingan dan Konseling, 1(3), 90-94.

Rosjidan. (2002). Rekonseptualisasi Konsep BK dan Implikasinya pada Pola Pendidikan Konselor. Makalah disajikan pada Seminar dan Lokakarya Nasional Standardisasi Profesi BK, Jurusan PPB FIP UNY. Yogyakarta, 24-25 Oktober 2002. 
Zamroni, M. (2009). Filsafat

Komunikasi: Pengantar

Ontologis, Epistemologis,

Aksiologis. Yogyakarta:

Graha Ilmu. 